\title{
An ethnography of parliamentary ethnographers: riffs, rhythms and rituals in their research
}

Social science has witnessed a growing respect towards ethnography albeit in an uneven way across regions and disciplines [1]. The tolerance for ethnography in parliamentary studies seems to be far higher in the United Kingdom (UK) than in the USA, but perhaps less fulsome than it is in France (Rozenburg, 2018). This is hardly surprising as the first ethnographic study of a parliament in Europe was carried out by Marc Abélès on the French Assembly and the relationship between the local and the centre in French politics $(1991,2000)$. Assessing attitudes among scholars towards ethnography requires an ethnography in itself, and this is a complex task because it demands more than a survey of outputs. Just as parliaments should not only be judged by the laws, policies and other texts they produce but by its embodied performances, so too the history of any branch of scholarship requires more than a study of publications. The community of ethnographic enquirers in parliaments is not only writers but also students, networkers, speakers, activists and teachers, with allies and critics in the academy but also in civil society as well as organisations of the state, contending with a web of academic hierarchies and national or disciplinary regimes and norms. Furthermore, what and how they study is not only shaped by their location and discipline but their own varying sources of inspiration, habitus and identity. In this essay, I will merely offer some preliminary insights into the thought collective of ethnographers of parliament.

\section{An ethnography of ethnographers of parliaments}

Who are the community of ethnographers in parliamentary studies? For anthropologists (such as myself), a "community" is usually defined by the members themselves, whether it is a village, profession, caste or a religious group, as we see it as more of an idea and constellation of relationships than a group bounded by formally established characteristics. But in reality, community members often argue among themselves about what it means to be within the boundaries of a village or religious group (e.g. to be Jewish or Muslim) or within a discipline, such as anthropology. The extent to which people self-identify as ethnographers is influenced in part by the disciplinary processes within their discipline. Until recently, despite the occasional and popular ethnographies undertaken political scientists, notably the breathtakingly innovative Home Style by Fenno (1978) and ethnographically informed studies by Puwar (2004), Leston-Bandeira (2016), Rai and Spray (2019) and Prior (2019), as well as self-identified ethnographies by Geddes (2020) and Miller (2021) in the UK alone, political science was dismissive of ethnographic research, or what were assumed to be "microstudies", for their lack of capacity for finding causal links, for inadequate generalising and for their occasional narcissism (see next section for details). Conversely, anthropologists have shown signs of being proprietorial about "ethnography," with reviewers of grant applications complaining that proposed ethnographic studies were insufficiently reflexive or weakened by the absence of an anthropologist [2]. So, there has been little incentive and some disincentives to claiming an "ethnographer" as your identity if sitting in the discipline of political science.

What were the influential turns to ethnography by politics scholars in the UK? Rai's large Leverhulme funded programme looking at rituals in parliaments in India, South Africa and

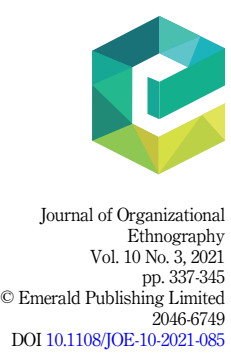


JOE
10,3 the UK was ethnographically inclined even if the researchers in that coalition did not call themselves ethnographers (Rai, 2010; Rai and Johnson, 2014). Since then we have witnessed a flowering of political ethnographies. Geddes published a monograph as part of a political ethnography series, even winning the Political Science Association's Mackenzie prize 2021 for best political science book with Dramas at Westminster (2020). Geddes and Rhodes (2018) outline three sources of inspiration: Rhodes's and Bevir's interpretive and antifoundationalist approach, Shirin Rai's (2010) work on rituals and my anthropology of parliament Crewe (2005). Rhodes and Bevir were key to making it respectable within political science to use observation to make sense of political institutions and politicians at work, partly through their explanations of ethnography as a methodology but also doing it themselves, e.g. Rhodes book on Everyday Life in British Government (2011). If such wellestablished political scientists were taking it seriously, it became more possible for others to do so too. The latest one is Cherry Miller's Gendering the Everyday in the UK House of Commons (2021), merging Butler's theory of performativity with feminist new institutionalism to look at how parliamentary actors' performances of gender are shaped by their institutional environment.

Several other disciplines have begun to make use of ethnography in their study of parliaments. The linguist Silvia Shaw used ethnographic methods several decades ago to look at the speech of women and men MPs in the House of Commons (2002). Management scholar Sabina Siebert has been undertaking innovative walking interviews in the Scottish Parliament as well as the Palace of Westminster (2020). Arguably, some oral histories overlap in some ways with ethnographies. Emma Peplow and Priscilla Pivatto's the Political Lives of Postwar British MPs (2020) offers similar material in their extracts of interviews with 170 UK MPs because they have been broad in their conception about what is relevant to political work and share an understanding of the limits to interviewing, a topic I will return to below. But the main discipline that has cornered the market for ethnographies of parliament is anthropology. In the Anthropology of Parliaments, I offer an overview of what ethnographers have written about parliaments and parliamentarians in 34 countries across all the continents (2021), beginning with research in the US Congress (1985) and ending with forthcoming studies by my colleagues in Myanmar and Ethiopia [3].

The vast majority of these ethnographers are anthropologists, but we remain a tiny group globally because our training inclines us towards a critical view of elites and the harm they cause when in positions of power. Anthropologists of parliament, like many other ethnographers who see clearly the violence in politics, have to grapple with uncomfortable situations of complicity when getting up close to politicians and avoiding a rush to judgement, which perhaps keeps others away. Political science ethnographers have to deal with a different discomfort - the risk of being overlooked for promotion, grants and even jobs for employing methods that are seen as sub-standard. Those who throw themselves into fully embedded ethnographic work early in their career - notable Geddes and Miller - deserve the recognition of scholarly heroes. The picture gets even more complex if you map discipline onto nationality, gender and race. Ethnographers tend to reside in the "Global North" and are predominantly white. The position of academics of colour and those in the "Global South" is even more precarious than other groups, so the barriers to turning to ethnography are even greater.

To understand ethnography, as opposed to other approaches to the study of parliament, you have to consider both theory and method. For anthropologists, these are entangled in ways that make it difficult to separate the two. Rather than writing about theory and then method, I will reapply a distinction I have made in relation to politicians' work - disentangling riffs, rhythms and rituals - to the work of ethnographers. In the next section, I will draw out some of the epistemological differences between ethnographers of parliaments from different disciplines and the rhythms and rituals involved in producing their scholarship to convey the commonality and diversity within this tiny global community. 


\section{Ethnographers' riffs, rhythms and rituals}

Now that we have some sense of the disciplinary range of the ethnographers of parliaments and examples of what they have published so far, it seems appropriate to ask some questions about how they think and what they do. Unsurprisingly, we will find some common threads in the thinking of all ethnographers but also significant differences. So, in some ways we are one thought collective, in Fleck's sense of a community that shares assumptions and ways of seeing the world, and in other ways we are several thought collectives with fundamentally different epistemologies (1981). To understand researchers' ideology it is revealing to investigate their theory of knowledge, how it is acquired, exchanged and contested, as this will obviously underpin how they deal with their own data gathered through research. How ethnographers theorise about ideology and knowledge - how politicians think, what they value and what rhetoric they use and also how they develop their own thinking, values and rhetoric - is partly expressed through disagreement and partly taken for granted.

This task is made easier by the ethnographers who are reflexive about their own ideological assumptions and how they differ from positivist researchers. Geddes and Rhodes point out that non-ethnographic parliamentary studies in the UK can be strangely lacking in theory: descriptive, normative and often focused on evaluating the effectiveness of the legislatures in their scrutiny roles (2018). Quantitative parliamentary scholars have a habit of creating typologies of theories that often amount to little more than path dependent causality, avoiding questions about why politicians act as they do if the answer is not easily measured (Crewe, 2021). On the other side, political scientists have complained that micro-studies do not generate generalisations, for example, "there was little leverage to explain the effect of institutional variation" (Martin et al., 2014, p. 9). By making a distinction between research that is either addressing (1) descriptive and interpretive questions or (2) causal questions (preferably through design experiments), some imply that qualitative research lacks theory (e.g. Druckman et al., 2014, p. 194). Miller has pointed to an ambivalence towards ethnography by mainstream parliamentary scholars; on the one hand, they tend to be open-minded about methodology, but at the same time, there has been some criticism of other disciplines: "[a]nthropologists, cultural historians, sociologists and linguists tend to 'depoliticise' parliament by reducing the actions of its members to everyday human conduct instead of seeing the politically constitutive aspects of acting parliamentarily" (Palonen as cited by Miller, 2021, p. 52).

So let us consider these critiques. Palonen is right that ethnographers share an interest in the everyday (Apter, 1987; Abélès, 1991; Busby, 2013; Crewe, 2015, 2021; Abram, 2017; Rai and Spray, 2019; Ahmed, 2019; Geddes, 2020; Miller, 2021). For example, Rai's and Spray's subsequent in-depth study of women MPs, based on interviewing, observation and being embedded, is highly ethnographic with its methods and commitment to multi-disciplinarity but above all in their attention to the everyday (2019). They have a sense of history (studying women MPs for over 10 years), geography (paying attention to how people navigate and make use of space) and theatre (seeing the performativity in politicians' everyday speech and action). But rather than ignoring the politically constitutive aspects of acting parliamentarily, it is precisely through the everyday that we find the building bricks, performative acts and relational discourses that, when seen with a sense of historical and geographical detachment, allow us to make statements about what constitutes political work. Since Bourdieu wrote $A n$ Outline of a Theory of Practice (1977), anthropologists and most ethnographers do indeed theorise about the relationship between particular everyday moments, critical events (Das, 1995) and broader patterns of structure and interaction. The anthropological failure to address the macro was a valid criticism half a century ago but is no longer true.

Underlying these reciprocal critiques are contrasting views about the role of causality, subjectivity and reflexivity in theory-building. Causality in positivist science and social science prioritises predictability. The reason they rely on the idea of path dependency is to respond to the expectation that they can anticipate future behaviour, in part influenced by a
Parliamentary ethnographers 
normative agenda about improving political worlds. If you lean towards the idea that human interaction is inherently unpredictable, which in my case I do through a mix of pragmatic philosophy and complexity science (along with my colleague Mowles, 2015), then the search for causal connections becomes quite different. To illustrate this point, in the mini-histories I wrote about a by-election, the making of a bill and the expenses scandal; the aim was to make the accounts as plausible as possible by reflecting on a plurality of views about what happened and employing a range of methods to cross-check people's claims. The findings of these minihistories do not make it possible to predict precisely how another bill might be transformed into law, for example, but generalisable patterns can easily be found. In the House of Commons acting parliamentarily means using evidence to rationalise your viewpoint; in the chamber, you can do so with reference to your party's position, whereas in select committee the expectation is that you rise above party politics and act as one entity (2015). Ethnographies offer a treasure trove of generalisations about acting parliamentarily.

In the Anthropology of Parliaments, my intention is to draw out the similar and different patterns between parliaments to demonstrate how ethnographers build theory historically. Ethnographic explanation is, as Bevir puts it, narrative (2006). Rather than assuming and testing a specific theory in advance - whether functionalism, rational choice or institutional sociology, as Saint-Martin explains in relation to the topic of ethics in parliament ethnographers assume that their theory will rely on an idea of social embeddedness (SaintMartin, 2020). While rational choice theory is closed, the approach to causality in a socially embedded theory is open; it is the task of the inquiry to discover what connects to what, how, why, where and for whom, in an abductive rather than either inductive or deductive way (Crewe, 2021, p. 198). Ethnographers clearly align with a view of the world where politicians are not just influenced by the self-interest of rational choice theory or the rules of institutionalist theory but embedded in complex social, political, economic and cultural practices that require investigation rather than being assumed. So, in contrast to positivist scholars hypothesising about what is going on in the world and using a scientific method to prove or disapprove their ideas, ethnographers work in a more participatory way - finding out how people think with less rigidity and judgement. Your theory builds on the theories of earlier scholars, by agreeing or disagreeing, but in an iterative and complex process rather than binary fashion.

Turning to the second critique of ethnography, in my view it is a mistake to respond to the accusation that ethnographic accounts are merely subjective with a yes or no answer; rather I would question the premise of the question. As our scholarly cousins, oral historians Peplow and Pivatto write as follows:

People construct memories in the present, about the past, with an eye to the future. We are not searching for some kind of "objective truth" in these interviews, and they should be treated in this way. As many oral historians argue, an oral history interview is a narrative told by the interviewee at the time of recording in collaboration with the interaction: the "interaction between narrative, imagination and subjectivity on the one hand, and plausibly ascertained facts on the other" (2020, p. 4).

But I would argue that ethnography is aspiring to go further towards the search for objective truth, even if it can never be literally reached, by taking account of endless subjectivities and diverse interests, views and relationships. Arendt wrote about this beautifully in relation to political engagement but it relates equally to research:

The more people's standpoints I have present in my mind while I am pondering a given issue, and the better I can imagine how I would feel and think if I were in their place, the stronger will be the capacity for representative thinking and the more valid my final conclusions, my opinion (1977, p. 241).

While ethnographers might agree relatively easily with the idea that objectivity is a process, rather than a fixed position, the most contentious aspect of our theory and method is the role that reflexivity has within this. Ethnographers take different positions on this. On the one 
hand, I have argued that without reflexivity, ethnography can never achieve rigour (2021: 11-13). You uncover what people take for granted; you have to consider both your own assumptions as a researcher but also what impact this meeting of different cultures, bodies of knowledge and interests has on your own inquiry. However, others are more sceptical. Rhodes warned, "critical self-awareness is essential but the danger is that the text becomes about the researcher; a diary of his or her involvement in the field. An excess of reflexivity spills over into a narcissism that is as unpalatable as it is boring" (2017, p. 52). We can agree that self-absorbed reflexivity is dull but the point of being reflexive is not to write about yourself, the author, as much as the complex interaction between the representer and represented, the relationships that the researcher has with his/her interlocutors. If an author is too (1) involved in their own experience, then they become narcissistic, or (2) detached from their interlocutors, then they lose the theoretical possibility of finding a plausible account. To do persuasive and exciting research, then Norbert Elias's advice about involved detachment is just as relevant to today as it was when he first wrote about it in the 1950s (1987). It is extremely difficult to avoid both narcissism and dishonest detachment, but the difficulty is not an excuse for avoidance.

It will become clear how theory is entangled with method when we consider the relationships formed between researcher and interlocutors in the everyday process of doing an inquiry. I am taken with Ingold's (2018) point we learn with our interlocutors rather than studying them as if they were objects, so the social distance during different activities will vary if you view the process as participatory. The parliamentary scholars who achieve the anthropological gold standard of participant observation to the fullest extent are parliamentarians, notably Lord Norton of Louth, a peer since 1998, and parliamentary officials, such as my co-authors Paul Evans (Crewe and Evans, 2018) and Andrew Walker (Crewe and Walker, 2019). In my research, I have relied heavily on collaboration with parliamentary scholars when creating as wide-ranging as possible rhythms of enquiry to allow for intense involvement but detachment at the same time (see Table 1).

The job of finding good methods of inquiry is never complete. My current interest is to expand more toward embodied ways of doing research, learning from Sabina Sierbert's

Rhythms of research in the Westminster parliament 1998-2021 (Emma Crewe)

\section{Mini-histories}

House of lords bill 1999

Selection of a candidate 2013

Eastleigh by-election 2013

Children's and families bill 2012-14

History of expenses scandal 2016-19

Chairs of select committees 2019

MPs in constituencies 2018-

\section{Texts, digital and observation}

Ethnographies, political science books/journal articles, biographies, memoirs, hansard, legislation, evidence to committees, parliament and other websites/blogs,

Twitter, political TV/radio/print, letters, reports

Chamber and select committees meetings

Staff meetings, staff/MP meetings

APPGs, social functions and other meetings

Nine constituencies: Surgeries and meetings
Parliamentary

341

\section{ethnographers}

(1)

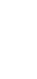

15 chapters and journal articles Six books (including 1 ethnography of the house of commons, one of the house of lords) Radio programmes, podcasts and talks Network/website: www.grnpp.org More on www.soas.ac.uk/staff/staff44316.php and www.emmacrewe.com 
JOE
10,3

342

walking ethnographies of parliament (2020) and the work of visual anthropologists (Cox et al., 2016) to capture the rhythms of political work more evocatively.

My impression is that political science ethnographers of parliament have a tendency to undersell their own methods as well as the ethnographic approach, downplaying the more humanity-sounding aspects of their enquiries and defining ethnography too narrowly. In one of Miller's summaries, she writes that she used three types of research material: "ethnography, in-depth (elite) interviews and documentary analysis. The book's emphasis on the everyday is not one of distinct level or scale of politics but a way of exploring thingsseeking connections, descriptive marks and gestures, ambiguity, agency and subjectivity" (2021, p. 52). I would include interviews and analysis in my description of the work of doing ethnography, and she is possibly underestimating the extent to which participation was an important source - she was inducted, trained, spoke informally to people in corridors, watched debates, submitted freedom of information requests (finding out the gendered breakdown of parliamentary staff, for example, Miller, 2021, p. 72) and used whatever was necessary to answer her puzzles. Another aspect of what makes Miller more anthropological than most political scientists is her reflection on how she treated MPs and how they responded to her (Miller, 2021, pp. 85-86). When she found herself almost employing my tactic of flattering MPs (which I hasten to say I only do if I mean what I say, which casts some doubt on whether flattery is precisely the right word), as a young woman, she found it riskier than I did as someone fast approaching the wrong side of middle-age. She is too self-critical when she says her approach is not intersectional; while impossible to be comprehensively so, she has written not only about gender but also age and class, and she underplays the capacity of her approach for generalisability. I would suggest that what Miller has achieved in her ethnography is far more significant that she claims herself.

Finally, what are the rituals that ethnographers of parliament find themselves in? We share many in common with other academics. We teach in classrooms - making presentations, facilitating discussion or break out groups, set assignments and mark them; we give presentations at workshops, seminars, roundtables and conferences, each with their own rules, hierarchies and modes of discussion; and we publish blogs, journal articles and books. Publishing has its own rituals whereby you navigate a strange mix of online portals, responding to reviewers, submitting drafts for blind review and publicising your efforts. But we have rituals of our own as ethnographers too, arising from the riffs and rhythms I have outlined above. Ethnographic rituals usually aim to reduce social distance. While a structured questionnaire or interview keeps the informant at arms' length, in the case of the former not even meeting face to face, an informal conversation in the corridor can be intimate in comparison. Informal conversation and gossip are usually a vital part of ethnography. Ethnographers usually try and challenge hierarchies in the relationship between the researcher and researched on the assumption that the researcher is often in a relative position of power, by joining into the lives of interlocutors and seeing what emerges rather than deciding on their behalf what matters most. In a structured interview, the engagement involves a set introduction and pre-determined questions, so the ritual is rigid and repetitive in the way it is enacted. They are rarely used by ethnographers who tend to prefer a semi-structured or unstructured encounter, which allows more room for manoeuvre by the interviewee, so they can jointly shape the direction that the conversation takes. So the rituals of an ethnography require improvised phronesis or practical judgement as much as preparation and careful design.

\section{An unequal global thought collective}

To complete even a rough sketch of ethnographers of the parliament, I need to say something about how we relate to each other. Beginning with the example of the micro-study of the country I know best, in the UK we are well-networked. Key organisers of various networks, such as the Political Studies Association's Parliaments Specialist Group, the Study of 
Parliament Group and the Centre for Democratic Engagement, are all sympathetic to ethnography, even encouraging scholars to present their findings and reflections in publications, at conferences and at other events. Cristina Leston-Bandeira's and Louise Thompson's Exploring Parliament (2018) contains chapters by ethnographers and parliamentary officials, showing a keen interest in the everyday workings of the parliament. Leston-Bandeira, a key figure in UK Parliamentary Studies, is trained in both political science and also anthropology. When I first began studying the parliament over 20 years ago, political science scholars would look at me with an either irritability or indulgence and ask "what are you exactly? A behaviourist?", but now they tend to say, "tell me more about ethnography". UK parliamentary scholars have become far more equal in terms of gender in recent years, but the community remains seriously under-represented by scholars of colour scholars, so ethnographers of the UK Parliament are disproportionately white relative to the UK population. There are important exceptions, such as Puwar and Rai, but both work on a broad range of other political and international relations topics as well.

The global picture reflects the hierarchies of academia on a larger canvas. In international journals about the parliament, white Australian, Canadian, European and US political scientists dominate as authors with a smaller number of published anthropologists of parliament and other political ethnographers from the same regions. But beyond the arena of formal peerreviewed publications, there are plenty of scholars in Africa, Asia, Middle East and Latin America studying their parliaments and their wider political worlds, even if their access to international journals is limited. A few of them are ethnographers - including anthropologists as referenced in (Crewe, 2021) and those given grants through the Global Research Network on Parliaments and People (ibid, pp. 189-193) - but they are relatively invisible to editors, conference organisers and grant-makers. Decolonising the global community of parliamentary scholars is an urgent challenge not just for the sake of academia but because democracy benefits from the scrutiny of diverse academics. Just as representation in parliament matters, we need better representation by race, nationality and ethnicity in our global thought collective.

Emma Crewe School of Anthropology, SOAS University of London, London, UK
Parliamentary ethnographers

\section{Notes}

1. My thanks go to the funders covering my time while writing this essay, the Arts and Humanities Research Council/Global Challenges Research Fund 2017-21 (AH/R005435/1) and the European Research Council 2019-24 (834986) - and my colleagues at the Global Research Network on Parliaments and People (Richard Axelby, Cristiane Brum Bernardes, Mitiku Gabrehiwot, Cristina Leston-Bandeira, and Amir Massoumian). Thank you also to Marc Geddes and Cherry Miller for their helpful comments.

2. I have heard this several times from political scientists but also when reading reviewing of grant applications reports about that colleagues have shown me.

3. The anthropologists of parliaments are too numerous to mention in this essay, but most of them are referenced in Crewe (2021). The research by ethnographers in Myanmar and Ethiopia was funded by grants awarded by the Global Research Network on Parliaments and People at SOAS and supported by the Arts and Humanities Research Council and Global Challenges Research Fund (2017-2021), directed by Meheret Ayenew, Emma Crewe, Ruth Fox, Niraja Gopal Jayal, Cristina Leston-Bandeira and Myat Thet Thitsar and managed from SOAS by Richard Axelby with Jas Kaur, Bethel WorkuDix and Amir Massoumian.

\section{References}

Abélès, M. (1991), Quiet Days in Burgundy. A Study of Local Politics, Cambridge University Press, Cambridge. 
JOE 10,3

Abélès, M. (2000), Un ethnologue à l'Assembleé, Odile Jacob, Paris.

Abram, S. (2017), "Contradiction in contemporary political life: meeting Bureaucracy in Norwegian municipal government", Journal of the Royal Anthropological Institute, Vol. 21 No. S1, pp. 27-44.

Ahmed, Z. (2019), "From shape shifting to collusion in violence: an ethnography of informal relationships between Bangladeshi members of parliament and their constituents", Political and Legal Anthropology Review, Vol. 42 No. 1, pp. 5-20.

Apter, A. (1987), "Things fell apart? Yoruba responses to the 1983 elections in ondo state, Nigeria", Journal of Modern African Studies, Vol. 25 No. 3, pp. 489-503.

Arendt, H. (1977), Between Past and Future, Penguin Books, New York.

Bevir, M. (2006), "How narratives explain", in Yanow, D. and Schawartz-Shea, P. (Eds), Interpretation and Method: Empirical Research Methods and the Interpretive Turn, Armonk, MY, Sharpe, pp. 281-290.

Bourdieu, P. (1977), An Outline of a Theory of Practice, Cambridge University, Cambridge.

Busby, A. (2013), "Normal parliament: exploring the organisation of everyday political life in an MEP's office”, Journal of Contemporary European Research, Vol. 9 No. 1, pp. 94-115.

Cox, R., Irving, A. and Wright, C. (2016), Beyond Text? Critical Practices and Sensory Anthropology, Manchester University Press, Manchester.

Crewe, E. (2005), Lords of Parliament: Manners, Rituals and Politics, Manchester University Press, Manchester.

Crewe, E. (2015), The House of Commons. An Anthropology of MPs' Work, Bloomsbury Academic, London.

Crewe, E. (2021), An Anthropology of Parliaments: Entanglements in Democratic Politics, Bloomsbury, London and New York.

Crewe, E. and Evans, P. (2018), "The significance of rituals parliament", in Cristina, L.-B. and Louise, T. (Eds), Exploring Parliament, Oxford University Press, Oxford.

Crewe, E. and Walker, A. (2019), An Extraordinary Scandal. The Westminster Expenses Crisis and Why it Still Matters, Haus, London.

Das, V. (1995), Critical Events: an Anthropological Perspective on Contemporary India, Oxford University Press, Oxford.

Druckman, J.N., Leeper, T.J. and Mullinix, K.J. (2014), "The experimental study of legislative behaviour", in Martin, S.T.S. and Strøm, K. (Eds), The Oxford Handbook of Legislative Studies, Oxford University Press, Oxford.

Elias, N. (1987), Involvement and Detachment, Basil Blackwell, Oxford.

Fenno, R. (1978), Home Style, House Members in their Districts Harper Collins, New York.

Fleck, L. (1981/1935), Genesis and Development of a Scientific Fact, University of Chicago Press, Chicago.

Geddes, M. (2020), Dramas at Westminster. Select Committees and the Quest for Accountability, Manchester University Press, Manchester.

Geddes, M. and Rhodes, R.A.W. (2018), "Towards an interpretive parliamentary studies”, in Brichzin, J., Krichewsky, D., Ringel, L. and Schank, J. (Eds), Soziologie der Parlamente, Politische Soziologie, Springer VS, Wiesbaden.

Ingold, T. (2018), Anthropology: Why it Matters, Polity, Cambridge.

Leston-Bandeira, C. (2016), "Why symbolic representation frames parliamentary public engagement", British Journal of Politics and International Relations, Vol. 18 No. 2, pp. 498-516.

Leston-Bandeira, C. and Thompson, L. (2018), Exploring Parliament, Oxford University Press, Oxford. Martin, S.T.S. and Strøm, K. (2014), The Oxford Handbook of Legislative Studies, Oxford University Press, Oxford. 
Miller, C.M. (2021), Gendering the Everyday in the UK House of Commons: Beneath the Spectacle, Palgrave Macmillan, Basingstoke.

Mowles, C. (2015), Managing in Uncertainty. Complexity and the Paradoxes of Everyday Organizational Life, Routledge, London.

Peplow, E. and Pivatto, P. (2020), The Political Lives of Postwar British MPs, An Oral History of Parliament, London and New York, Bloomsbury.

Prior, A.M. (2019), "Living this written life': an examination of narrative as a means of conceptualising and strengthening parliamentary engagement in the UK", $\mathrm{PhD}$ Thesis, ethnographers University of Leeds.

Puwar, N. (2004), Space Invaders: Race, Gender and Bodies Out of Place, Berg, London.

(2010), "Special issue ceremony and ritual in parliament", in Rai, S.M. (Ed.), The Journal of Legislative Studies, Vol. 16 No. 3, pp. 284-297.

Rai, S.M. and Johnson, R. (2014), Democracy in Practice, Ceremony and Ritual in Parliament, Palgrave Macmillan, Basingstoke and New York.

Rai, S.M. and Spray, C. (2019), Performing Representation. Women Members in the Indian Parliament, Oxford University Press, Oxford.

Rhodes, R.A.W. (2011), Everyday Life in British Government, Oxford University Press, Oxford.

Rhodes, R.A.W. (2017), Interpretive Political Science, Selected Essays, Vol. II, Oxford University Press, Oxford.

Rozenberg, O. (2018), "The belated love of French sociologists for parliaments", in Brichzin, J., Krichewsky, D., Ringel, L. and Schank, J. (Eds), Soziologie der Parlamente. Politische Soziologie, Springer VS, Wiesbaden.

Saint-Martin, D. (2020), "The comparative institutional analysis of parliamentary ethics", in Benoit, C. and Rozenberg, O. (Eds), Handbook of Parliamentary Studies, Interdisciplinary Approaches to Legislatures, Edward Elgar, Cheltenham.

Shaw, S. (2002), "Language and gender in political debates in the house of commons", Doctoral Thesis, Institute of Education, University of London.

Siebert, S. (2020), Restoration and Renewal of Parliament: Buildings as a Vehicle for Change, Project Report, University of Glasgow, doi: 10.36399/gla.pubs.223191.

Weatherford, J. (1985), Tribes on the Hill. The US Congress Rituals and Realities, Bergin and Garvey, Westport. 